\title{
Particle size distribution factor as an indicator for the impact of the Eyjafjallajökull ash plume at ground level in Augsburg, Germany
}

\author{
M. Pitz ${ }^{1,2}$, J. Gu ${ }^{1,2}$, J. Soentgen ${ }^{2}$, A. Peters ${ }^{1}$, and J. Cyrys ${ }^{1,2}$ \\ ${ }^{1}$ Helmholtz Zentrum München, German Research Center for Environmental Health, Institute of Epidemiology II, \\ 85764 Neuherberg, Germany \\ ${ }^{2}$ University of Augsburg, Environment Science Center, 86159 Augsburg, Germany
}

Received: 22 March 2011 - Published in Atmos. Chem. Phys. Discuss.: 6 June 2011

Revised: 2 September 2011 - Accepted: 7 September 2011 - Published: 9 September 2011

\begin{abstract}
During the time period of the Eyjafjallajökull volcano eruption in 2010 increased mass concentration of $\mathrm{PM}_{10}$ (particulate matter, diameter $<10 \mu \mathrm{m}$ ) were observed at ground level in Augsburg, Germany. In particular on 19 and 20 April 2010 the daily $\mathrm{PM}_{10}$ limit value of $50 \mu \mathrm{g} \mathrm{m}$ was exceeded. Because ambient particles are in general a complex mixture originating from different sources, a source apportionment method (positive matrix factorization (PMF)) was applied to particle size distribution data in the size range from $3 \mathrm{~nm}$ to $10 \mu \mathrm{m}$ to identify and estimate the volcanic ash contribution to the overall $\mathrm{PM}_{10}$ load in the ambient air in Augsburg. A PMF factor with relevant particle mass concentration in the size range between 1 and $4 \mu \mathrm{m}$ (maximum at $2 \mu \mathrm{m}$ ) was associated with long range transported dust. This factor increased from background concentration to high levels simultaneously with the arrival of the volcanic ash plume in the planetary boundary layer. Hence, we assume that this factor could be used as an indicator for the impact of the Eyjafjallajökull ash plume on ground level in Augsburg. From 17 to 22 April 2010 long range transported dust factor contributed on average $30 \%\left(12 \mu \mathrm{g} \mathrm{m}^{-3}\right)$ to $\mathrm{PM}_{10}$. On 19 April 2010 at 20:00 UTC+1 the maximum percentage of the long range transported dust factor accounted for around $65 \%\left(35 \mu \mathrm{g} \mathrm{m}^{-3}\right)$ to $\mathrm{PM}_{10}$ and three hours later the maximum absolute value with around $48 \mu \mathrm{g} \mathrm{m}^{-3}$ (61\%) was observed. Additional PMF analyses for a Saharan dust event occurred in May and June 2008 suggest, that the long range transported dust factor could also be used as an indicator for Saharan dust events.
\end{abstract}

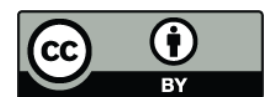

Correspondence to: M. Pitz (mike.pitz@hs-augsburg.de)

\section{Introduction}

Particulate matter (PM) is ubiquitously present in the atmosphere and originate from natural processes (e.g. erosion (soil, sea salt, desert dust), forest and bush fires, volcanoes) and anthropogenic emissions (e.g. traffic, industry, domestic heating, agriculture) as well as from formation in the atmosphere by nucleation processes or from gaseous precursors (secondary aerosol formation). Hence, the chemical composition of ambient PM is very complex and variable and finally, the composition of particles affects their transport and residence time in the atmosphere, solar radiation and deposition in the environment. All these factors in turn affect ambient air quality. For example, Birmili et al. (2008) showed that a wind-blown soil dust event in southern Ukraine led to extremely high mass concentration of $\mathrm{PM}_{10}$ (aerodynamic diameters $<10 \mu \mathrm{m}$ ) in central Europe.

In the European Union limit values for the mass concentration of $\mathrm{PM}_{10}$ were established since 2005 "to avoid, prevent or reduce harmful effects on human health and the environment as a whole" (Council Directive 1999/30/EC). The Directive 2008/50/EC permits under specific conditions (“... determined with sufficient certainty, and where exceedances are due in whole or in part to these natural contributions...") the subtraction of (I) re-suspension of particles (e.g. winter-sanding or -salting of roads) or (II) of natural source contributions (e.g. volcanic ash, desert and soil dust) from the measured PM mass concentration. The effects of natural sources on PM ground level are difficult to prove. First of all supplemental analyses of the origin of the air masses are mostly needed (e.g. satellite images, backward trajectories). In addition to $\mathrm{PM}_{10}$ mass concentration normally further measurements such as elemental composition and gaseous parameters are necessary to estimate the

Published by Copernicus Publications on behalf of the European Geosciences Union. 
contribution of the natural sources to the ambient PM concentration.

In this study, we will demonstrate a method for relatively rapid identification of natural dust events and estimation of their contribution to the increase of $\mathrm{PM}_{10}$ mass concentration in Augsburg, Germany using as an example the eruption of the Eyjafjallajökull volcano in Iceland, which was visually observed for the first time on 20 March 2010 (IES, 2010). The trajectory of the volcanic ash plume was tracked by the London Volcanic Ash Advisory Centers (VAAC) using a combination of infrared channels of satellite images and atmospheric dispersion modeling (VAAC, 2010). As a result of the advection of volcanic ash clouds over Europe, no-flying zones were established to prevent damage on aircrafts, which led to a closure of the most European airports from 15 to 21 April 2010.

The presence of the volcanic ash plume over Europe has been also demonstrated by aircraft measurements conducted directly in the Eyjafjallajökull ash plume e.g. by the research aircraft Falcon from the German Aerospace Center (Schumann et al., 2011). Some other studies demonstrate the presence of the volcanic ash plume indirectly by ground-based remote sensing measurements (e.g. Colette et al., 2011; Flentje et al., 2010; Gasteiger et al., 2011; Schäfer et al., 2011). Emeis et al. (2011) described the temporal and spatial structure of the volcanic ash plume by numerical simulations with the Eulerian meso-scale model. Thomas and Prata (2011) studied the feasibility of using sulphur dioxide $\left(\mathrm{SO}_{2}\right)$ as a tracer for the volcanic ash plume by comparing ash retrievals from the geosynchronous Meteosat satellite with $\mathrm{SO}_{2}$ measurements based on satellite sensors received from polar orbiting platforms.

Flentje et al. (2010) observed enhanced $\mathrm{SO}_{2}$ and particle number concentration levels simultaneously with the arrival of the Eyjafjallajökull ash plume in the time period 16 to 21 April 2010 at two mountain stations in the northern Alpine region in Germany; the Environmental Research Station (UFS) "Schneefernerhaus" (located $2650 \mathrm{~m}$ a.s.1., $300 \mathrm{~m}$ below the Zugspitze summit) and the Hohenpeissenberg Meteorological Observatory HPB ( $985 \mathrm{~m}$ a.s.1., $300 \mathrm{~m}$ above the surrounding countryside). However, the volcanic impact at HPB was partially masked by enhanced anthropogenic background. Colette et al. (2011) reported the most outstanding enhanced levels of $\mathrm{PM}_{10}$ mass concentration on 18 and 19 April 2010 for an urban background station in northern France (Mulhouse). A combination of atmospheric dispersion modelling, ground-based remote sensing measurements and chemical analyses of sampled particles were used for the estimation of the volcanic ash impact to the observed increase of ambient $\mathrm{PM}_{10}$ mass concentration. Schäfer et al. (2011) observed elevated particle number concentrations of ultrafine particles (UFP, diameter $<100 \mathrm{~nm}$ ) for the regional background stations UFS, HPB, and SSL ("Schauinsland", $1210 \mathrm{~m}$ a.s.l.) which can be assigned to particle formation in the volcanic ash plume from the gaseous precursor
$\mathrm{SO}_{2}$. In contrast, increased UFP at an urban background site in Augsburg, Germany could not be clearly identified as of volcanic origin because of the higher anthropogenic impact. The identification and quantification of volcanic ash impact to ambient $\mathrm{PM}_{10}$ levels measured on 19 and 20 April 2010 at five monitoring stations of the Bavarian air monitoring network (Andechs and Tiefenbach: regional background, Augsburg: urban background, München and Oberaudorf: traffic) was conducted in the Schäfer study by means of additional measurements, e.g. titanium content in $\mathrm{PM}_{10}$. Moreover, Schäfer et al. (2011) observed an increase of sulphate mass concentration in $\mathrm{PM}_{2.5}$ without any major $\mathrm{SO}_{2}$ peak during the volcanic ash plume episode in Augsburg. It indicates that a significant amount of the initial emitted $\mathrm{SO}_{2}$ was converted to sulphuric acid $\left(\mathrm{H}_{2} \mathrm{SO}_{4}\right)$ and sulphate mass concentration during transport of the volcanic ash plume. The $\mathrm{SO}_{2}$ concentrations in the volcanic ash plume were additionally reduced by increased dilution during the transport down to the monitoring site in Augsburg (484 m a.s.1.) and good vertical mixing and advection conditions. This assumption is supported by the observation that despite of rather low $\mathrm{SO}_{2}$ levels in Augsburg, an increase of $\mathrm{SO}_{2}$ concentrations was observed at monitoring sites at higher elevation, such as UFS or HPB site.

It indicates, that the identification of such natural events as volcanic ash plume, which could lead to a dramatical increase of ambient particle concentrations, is more difficult in urban areas than in rural or mountain areas. The reason for this is the impact of anthropogenic background which is much stronger in urban areas in comparison to rural areas or even mountain stations.

In this study we applied positive matrix factorization method using particle size distribution data in the diameter range $3 \mathrm{~nm}$ to $10 \mu \mathrm{m}$ for identification of the Eyjafjallajökull ash plume and estimation of the contribution of the Eyjafjallajökull ash plume to the $\mathrm{PM}_{10}$ mass concentration in Augsburg, Germany.

\section{Experimental}

\subsection{Sampling location}

The measurement site is located on the premises of the University of Applied Sciences (AUHS, $48^{\circ} 22^{\prime} \mathrm{N} ; 10^{\circ} 54^{\prime} \mathrm{E}$; $484 \mathrm{~m}$ a.s.1.) about $1 \mathrm{~km}$ south of the city center and is representative for urban background conditions in Augsburg, Germany (Cyrys et al., 2008). Additional details of the site have been reported by Pitz et al. (2008a, b). The volcano Eyjafjallajökull, Iceland is located around $2500 \mathrm{~km}$ away from Augsburg, Germany.

Because no gaseous pollutants were measured at the AUHS site, $\mathrm{SO}_{2}$ concentration from a measurement site of the Bavarian air monitoring network was used. This site at the Bavarian State Office for the Environment (AUBÜ) is 
located about $3.5 \mathrm{~km}$ away south of the AUHS site and is also considered as an urban background site.

\subsection{Measurement methods}

A Twin Differential Mobility Particle Sizer (TDMPS) system combined with an Aerodynamic Particle Sizer (APS, model 3321, TSI Inc., USA) was used to measure particle size distribution in the diameter range $3 \mathrm{~nm}$ to $10 \mu \mathrm{m}$. Additional information about the merging of TDMPS and APS data as well as for the evaluation of the calculated particle mass concentration from the merged size distribution can be found in the appendix A. The Black Carbon (BC) fraction of $\mathrm{PM}_{2.5}$ was measured with an Aethalometer (series 8100, Thermo Fisher Scientific Inc., USA). Details of the measurement devices and the applied quality assurance have been reported by Pitz et al. (2008a, b) and Birmili et al. (2010). Briefly, the merged particle size distribution and all relevant parameters of the devices were visually checked normally on daily base. In addition, for the APS (measurement range $>0.8 \mu \mathrm{m}$ ) a zero-point check and a check with monodisperse latex particles $(1.06 \pm 0.04 \mu \mathrm{m})$ was performed on monthly base.

\subsection{Positive matrix factorization (PMF)}

We used the receptor model PMF 3.0 from the US Environmental Protection Agency (EPA) to identify particle size distribution factor profiles and quantify factor contributions. The EPA PMF 3.0 software is free of charge available at EPA website (http://www.epa.gov/heasd/). PMF is a widely used receptor model for characterizing aerosol sources (Paatero, 1999). It decomposes the measured PM composition data (or size distribution data etc.) into sub factor profiles and factor contributions. Comparing it with previously used methods like principal components analysis, it has the advantage of more realistic non-negative constrains on factor profiles and contributions, and better scaling of the data by individually assigned uncertainties (Paatero and Tapper, 1994; Paatero, 1997). The application of PMF to particle size distribution data has been successfully conducted by Zhou et al. (2004) and Ogulei et al. (2007) and others. Compared with the application to particle chemical composition data, it is in parts more difficult to interpret because specific tracers are not present as normally available for chemical composition data. Hence, for an interpretation of the PMF factor contributions and factor profiles obtained from particle size distribution data, additional data like gaseous pollutants and meteorological data are helpful to allocate the PMF factors to possible sources. Nevertheless, as mentioned by Gu et al. (2011) using particle size distribution data has novel aspects in comparison of using chemical composition data. Particle size distribution can help to separate sources emitting very small particles with diameter $<50 \mathrm{~nm}$ while particulate chemical composition data can only separate sources composed of particles within the similar size range. Moreover, particle size distri- bution data can be obtained by (semi)automatic measuring instruments with high temporal resolution whereas for chemical composition data usually sampling times longer than one hour and subsequently labor intensive chemical wet analysis are necessary.

Because of marginal data coverage, three size channels $(3 \mathrm{~nm}, 3.4 \mathrm{~nm}$ and $10 \mu \mathrm{m})$ were excluded from the analyses, finally resulting in 64 size channels ( $3.8 \mathrm{~nm}$ to $8.8 \mu \mathrm{m}$ ). Four channels between 3.8 and $5.5 \mathrm{~nm}$, four channels between 0.75 and $1 \mu \mathrm{m}$ and three channels between 6.9 and $8.8 \mu \mathrm{m}$ were set to weak.

The measurement of particle size distribution provides no detection limit; hence we assumed the uncertainty of every channel to $10 \%$ (Yue et al., 2008). If the number concentration of a channel was zero, we assumed an uncertainty of $10 \%$ of the total mean of the respective channel. Moreover, an extra modeling uncertainty of $25 \%$ was applied to every size channel. The PMF analyses were performed for the time period 1 April to 31 May 2010 (Eyjafjallajökull volcano eruption) and in addition for the time period 1 May to 30 June 2008 (Saharan dust event).

Initially, we analyzed and compared different numbers of factors and we compared the results subsequently with each other. Based on these preliminary investigations PMF model with seven factors reveal the most plausible and interpretable results to characterize the potential particle sources. Moreover, multiple bootstrap runs were performed to test the stability and uncertainty of the model results. Bootstrap model generate new data sets by randomly selecting nonoverlapping blocks of samples with the same dimensions as the original data set. Each new data set is decomposed into profile and contribution matrices and these results from the bootstrap model will then be compared with the contribution of the base factors. The comparison will be assessed by correlation coefficients above a user-specified threshold normally set to 0.6 . The observed factors from every bootstrap model run are considered as mapped with a given base factor if the correlation coefficient is above the selected threshold and the respective bootstrap factor correlates best with the same base factor. The summary of all bootstrap model runs allows the user to review the PMF factors to evaluate the stability and robustness of the statistics given by the PMF method. In our study, all 100 bootstrap runs of the long range transported dust factor are mapped, showing that the PMF results are stable.

PMF results observed in this study showed the same number and profiles of the particle size distribution factors as already shown by Gu et al. (2011) for the same site in Augsburg in winter 2006/2007 where additional gaseous pollutants, online chemical compositions and meteorological data were used to assist interpreting the PMF results. 


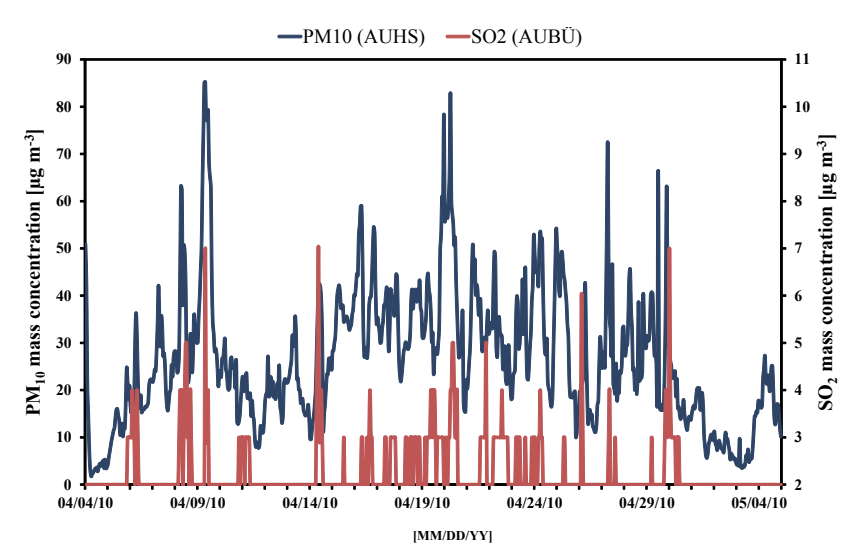

Fig. 1. Time series of hourly average $\mathrm{PM}_{10}$ mass concentration measured at the University of Applied Sciences (AUHS) and $\mathrm{SO}_{2}$ mass concentration measured at the Bavarian State Office for the Environment (AUBÜ) in Augsburg, Germany.

\section{Results and discussion}

In Fig. 1 the time series of the hourly average $\mathrm{PM}_{10}$ mass concentration measured at the University of Applied Sciences (AUHS) and the $\mathrm{SO}_{2}$ mass concentration measured at the Bavarian State Office for the Environment (AUBÜ) in the time period 4 April to 4 May 2010 is shown for Augsburg, Germany. In particular on 9 April and 19/20 April 2010 increased $\mathrm{PM}_{10}$ mass concentrations could be observed whereas the daily $\mathrm{PM}_{10}$ limit of $50 \mu \mathrm{g} \mathrm{m}^{-3}$ was only exceeded on 9 April at the AUHS site. At the other four measurement sites of the Bavarian air monitoring network in Augsburg partially exceeding of the respective threshold during the two time periods could be observed (data not shown). On the other hand, no increased $\mathrm{SO}_{2}$ concentrations were observed in the same time periods at ground level in Augsburg which is in contrast to other monitoring sites where elevated $\mathrm{SO}_{2}$ levels were observed in parallel to elevated $\mathrm{PM}_{10}$ levels (Flentje et al., 2010; Schäfer et al., 2011). Therefore, the clearly identification of the volcanic ash impact on ground level in Augsburg was not possible without additional information. In other words, it was not possible to distinguish whether the increased $\mathrm{PM}_{10}$ levels in Augsburg were caused by the Eyjafjallajökull ash plume or if the observed increased $\mathrm{PM}_{10}$ levels were caused by other local anthropogenic sources. Hence, PMF analysis was applied to particle size distribution data to identify the possible sources. The performed PMF analyses for April to May 2010 resulted in seven source factors with similar factor profiles as already found by Gu at al. (2011) for Augsburg in winter 2006/2007. As described by $\mathrm{Gu}$ and colleagues those factors could be associated to (I) nucleation particles, (II) fresh traffic emissions, (III) aged traffic emissions, (IV) stationary combustion, (V) secondary aerosols, (VI) re-suspended dust, and (VII) long range transported dust. For more details regard-

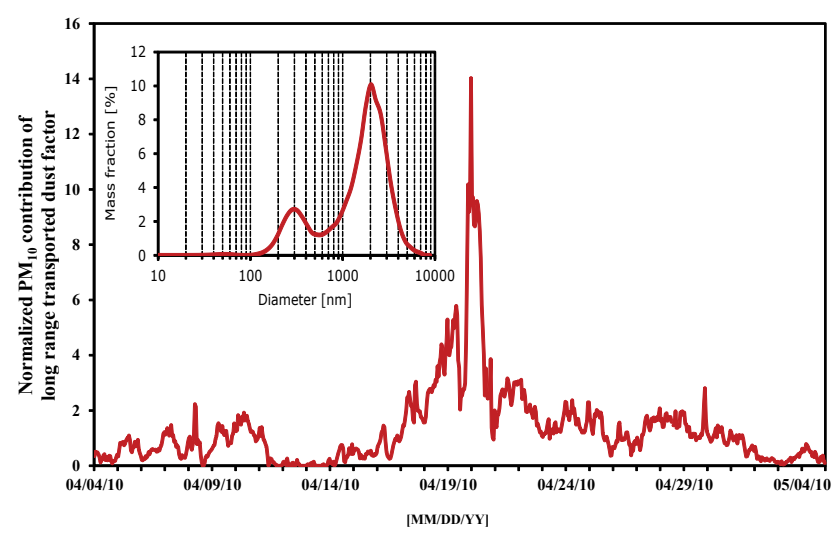

Fig. 2. Time series section of normalized hourly average $\mathrm{PM}_{10}$ contribution of long range transported dust factor at the University of Applied Sciences in Augsburg, Germany (average of all contributions for each factor is 1 for the total time period April to May 2010). The percentage of the particle mass size distribution is shown in the inset.

ing the interpretation of the PMF factors please refer to $\mathrm{Gu}$ et al. (2011).

In Fig. 2 the time series section from 4 April to 4 May 2010 for the normalized factor contribution to $\mathrm{PM}_{10}$ (the average of all contributions for each factor is 1 for the total time period April to May 2010) and the percentage of particle mass size distribution of the factor which was associated to long range transported dust is shown. The relevant particle mass concentration size range for the long range transported dust factor was between 1 and $4 \mu \mathrm{m}$ with the peak maximum at $2 \mu \mathrm{m}$. A remarkable large peak of the long range transported dust factor was found around midnight on 19 April which coincided with the $\mathrm{PM}_{10}$ peak shown in Fig. 1. It seems that the long range transported dust factor was in fact (at least partially) influenced by the Eyjafjallajökull ash plume. Our findings for increased $\mathrm{PM}_{10}$ mass concentration in parallel to the increase of the factor contribution agree very well with the observed findings by Schäfer et al. (2011) at the same site. In the Schäfer study increased secondary sulphate mass concentrations during the volcanic ash impact were observed which were attributed to the formation from the gaseous precursor $\mathrm{SO}_{2}$ during transport of the Eyjafjallajökull ash plume. Moreover, our findings are in good agreement with the findings of Schumann et al. (2011). During the flight with the research aircraft Falcon over southern Germany minor ash mass concentrations on 9 April 2010 and increased ash mass concentration on 19 April were observed.

Figure 3 shows the hourly average particle volume size distributions (spherical shape assumed) for the time period largely affected by the volcanic ash plume (19 April 19:00 to 20 April 10:00 UTC+1) in comparison to the hourly average of the long-term time period 2005 to 2010 . Normally, a bimodal particle size distribution with a prevalent bias to particles smaller than $1 \mu \mathrm{m}$ could be observed as indicated 


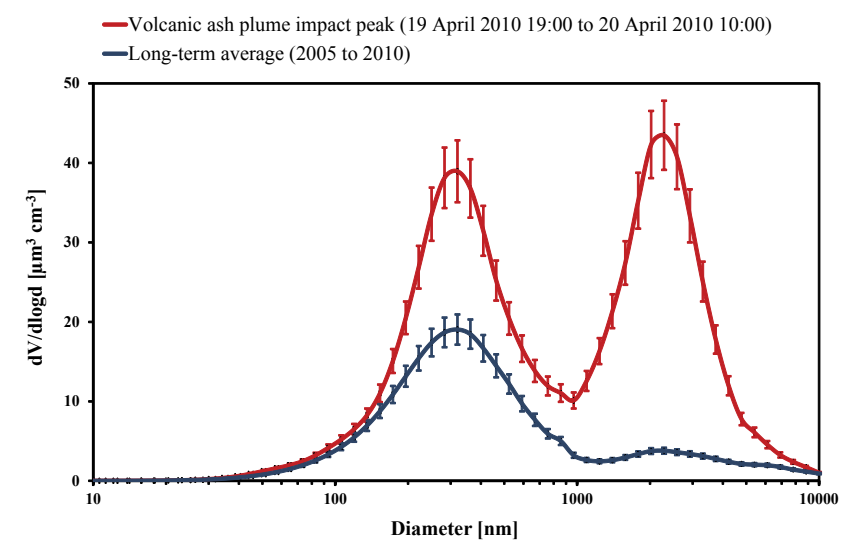

Fig. 3. Hourly average particle volume size distributions during the volcanic ash plume impact in comparison to the long-term average of the years 2005 to 2010 at the University of Applied Sciences in Augsburg, Germany. The error bars represent $\pm 10 \%$.

by the blue line representing the long-term hourly average. During the volcanic ash plume impact episode a drastic increase in particular of particles with diameters greater than $1 \mu \mathrm{m}$ could be observed.

As shown in Fig. 4 starting on 17 April lasting for about 6 days until 22 April 2010 increased particle mass concentrations of the long range transported dust factor could be observed. In this time period the long range transported dust factor contributed on average $30 \%\left(12 \mu \mathrm{g} \mathrm{m}^{-3}\right)$ to the $\mathrm{PM}_{10}$ mass concentration. In the evening of 19 April 2010 at 20:00 UTC+1 the maximum percentage of the Eyjafjallajökull ash plume to the $\mathrm{PM}_{10}$ mass concentration with around $65 \%$ $\left(35 \mu \mathrm{g} \mathrm{m}^{-3}\right.$ ) was observed. Three hours later the maximum absolute value accounted for around $48 \mu \mathrm{g} \mathrm{m}^{-3}(61 \%)$ to the $\mathrm{PM}_{10}$ mass concentration. During the non-affected time period from April to May the long range transported dust factor contributed on average $14 \%\left(3 \mu \mathrm{g} \mathrm{m}^{-3}\right)$ to the $\mathrm{PM}_{10}$ mass concentration. Additional analyses of the $\mathrm{BC}$ concentration at the AUHS site showed weak correlation between the long range transported dust factor and the $\mathrm{BC}$ mass concentration. Nevertheless, on 20 April at 06:00 UTC+1 in the morning increased $\mathrm{BC}$ mass concentrations were observed in parallel to increased particle mass concentrations of the long range transported dust factor and $\mathrm{PM}_{10}$ (Fig. 4). It means, that the second $\mathrm{PM}_{10}$ mass concentration peak $\left(83 \mu \mathrm{g} \mathrm{m}^{-3}\right)$ was associated not only to volcanic ash plume $\left(32 \mu \mathrm{g} \mathrm{m}^{-3}\right)$, but also to local particles generated by anthropogenic sources in the city of Augsburg which could be mainly assigned to stationary combustion $\left(17 \mu \mathrm{g} \mathrm{m}^{-3}\right)$, fresh traffic $\left(7 \mu \mathrm{g} \mathrm{m}^{-3}\right)$ and aged traffic $\left(3 \mu \mathrm{g} \mathrm{m}^{-3}\right)$ emissions.

In the recent past Bruckmann et al. (2008) described an outbreak of Saharan dust between 27 May and 01 June 2008 causing high $\mathrm{PM}_{10}$ levels north of the Alps. To test whether the contribution of the long range transported dust factor to $\mathrm{PM}_{10}$ levels is also increased during the Saharan dust out-

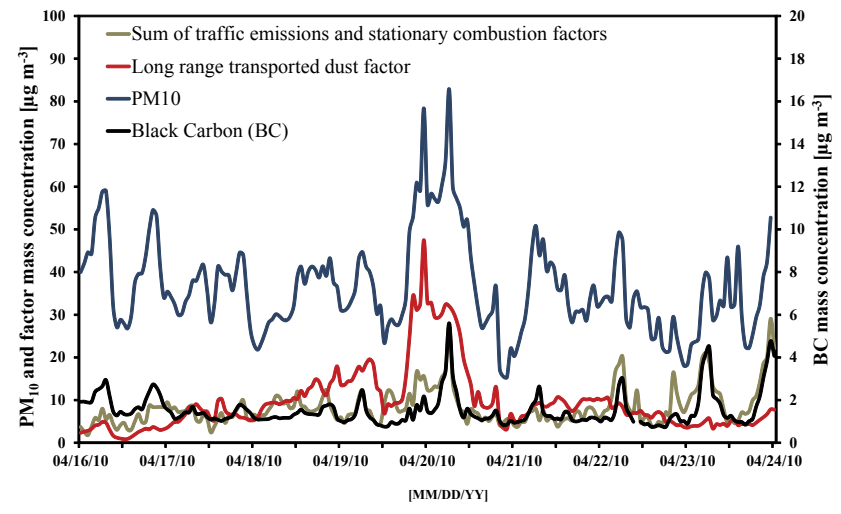

Fig. 4. Time series section of hourly average mass concentration of $\mathrm{BC}, \mathrm{PM}_{10}$, long range transported dust factor and sum of traffic emissions and stationary combustion factors from 16 April 2010 to 23 April 2010 at the University of Applied Sciences in Augsburg, Germany.
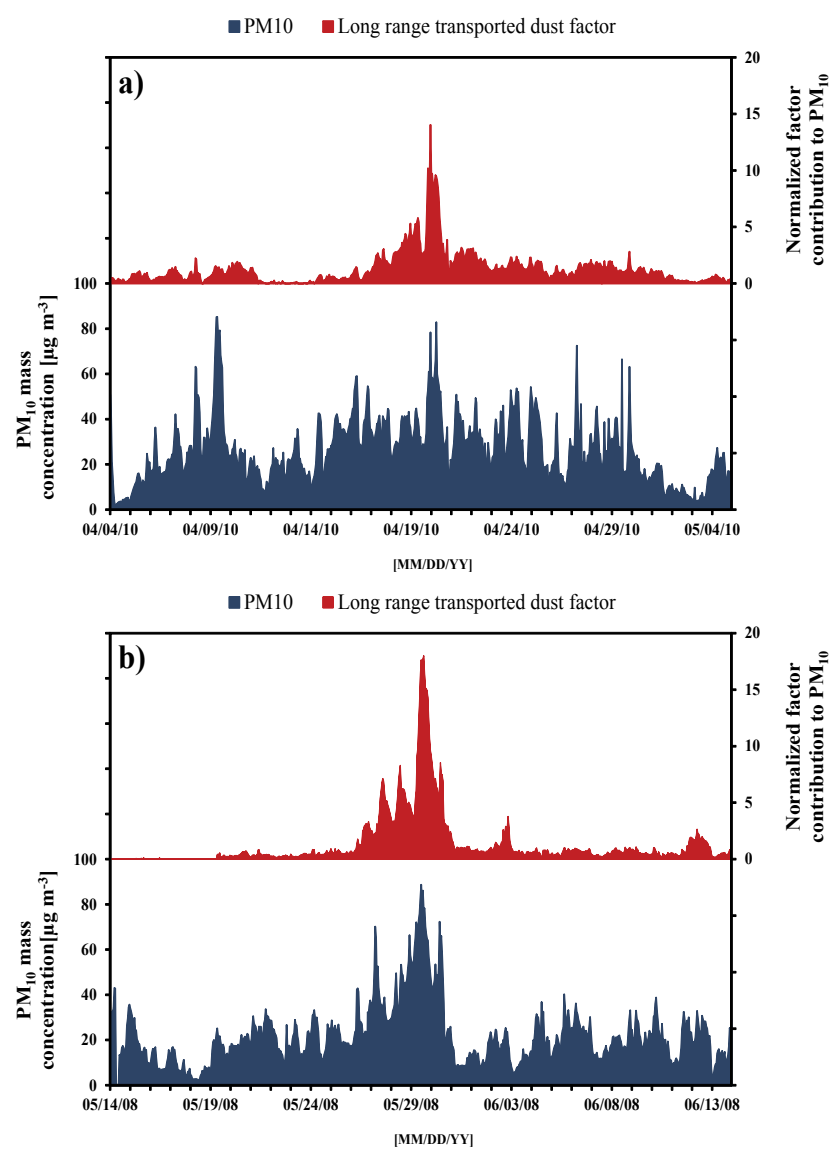

Fig. 5. Time series section of hourly average $\mathrm{PM}_{10}$ mass concentration and normalized $\mathrm{PM}_{10}$ contribution of long range transported dust factor during (a) Eyjafjallajökull ash plume impact 2010 and (b) Saharan dust event 2008 at the University of Applied Sciences in Augsburg, Germany. 
break (and not only during the volcanic ash episode), we also applied PMF method for the time period May to June 2008. PMF analyses resulted also in seven particle size distribution source factors with similar factor profiles as already abovementioned for the time period April to May 2010 where the Eyjafjallajökull ash plume impact was observed. In Fig. 5 the time series section of the $\mathrm{PM}_{10}$ mass concentration and the normalized $\mathrm{PM}_{10}$ contribution of the long range transported dust factor from 4 April to 4 May 2010 for the Eyjafjallajökull ash plume impact (Fig. 5a) and from 14 May to 31 June 2008 for the Saharan dust event (Fig. 5b) are comparative shown for the monitoring site at the University of Applied Sciences in Augsburg. A clear increase of the long range transported dust factor contribution was also observed during the Saharan dust event which correlates with the increased $\mathrm{PM}_{10}$ levels. It indicates that the long range transported dust factor could be used for identification of such natural events as volcanic ash plume in April 2010 as well as Saharan dust episodes. A check of the contribution of the long range transported dust factor to $\mathrm{PM}_{10}$ of the years 2005 to 2010 revealed that such events occur approximately once to twice per year.

\section{Conclusions}

$\mathrm{PM}_{10}$ and $\mathrm{SO}_{2}$ concentration which are normally available in air monitoring networks could not be used for identification and quantification of natural dust impact as the Eyjafjallajökull ash plume at urban ground level in Augsburg, Germany without any additional data. Normally, additional analyses of daily $\mathrm{PM}_{10}$ filter samples for chemical composition are necessary to estimate the volcanic ash plume contribution to the $\mathrm{PM}_{10}$ levels (assuming that the chemical composition of the volcanic ash is known). In this study, a PMF factor which was associated to long range transported dust (mass peak between 1 and $4 \mu \mathrm{m}$ with a maximum at $2 \mu \mathrm{m}$ ) was used as an indicator for the impact of the Eyjafjallajökull ash plume at ground level in Augsburg. On 19 April 2010 at 20:00 UTC+1 the maximum contribution of the long range transported dust factor to $\mathrm{PM}_{10}$ with about $65 \%\left(35 \mu \mathrm{g} \mathrm{m}^{-3}\right)$ was observed and the maximum absolute value of around $48 \mu \mathrm{g} \mathrm{m}^{-3}(61 \%)$ was observed three hours later. Moreover, it could be shown that the long range transported dust factor could also be used as an indicator for a Saharan dust event in May and June 2008.

We showed in our study, that source apportionment using PMF method applied to hourly average ambient particle size distribution data offers a quite simple possibility to separate sources of a heterogeneous ambient mixture of different particulate sources. For the identification of natural sources (e.g. volcanic ash or desert dust), which occur for example in Augsburg approximately once to twice per year considering 2005 to 2010, particle size distribution (also of super micron particles) and additional information of the origin of the air masses such as satellite images or backward trajectories should be available. Further investigations of natural contributions to PM and comparisons with independent analyses methods are necessary to demonstrate the accuracy of the PMF method.

\section{Appendix A}

\section{Apparent particle density}

For the conversion of the particle size distribution to particle mass concentration a spherical shape of the particles and an apparent mean density have to be assumed. Moreover, an effective density for the adaption of the aerodynamic diameter of the APS and the mobility diameter of the TDMPS has to be assumed.

In this study an effective density of $1.7 \mathrm{~g} \mathrm{~cm}^{-3}$ in the overlap range of 800-900 $\mathrm{nm}$ was assumed resulting in an excellent agreement of the merged TDMPS and APS size distributions as already shown by Pitz et al. (2008b).

For the calculation of the $\mathrm{PM}_{10}$ mass concentration from the merged size distribution of TDMPS and APS ( $3 \mathrm{~nm}$ to $10 \mu \mathrm{m})$ a mean apparent density of $1.5 \mathrm{~g} \mathrm{~cm}^{-3}$ was used according to Pitz et al. (2003, 2008a, b). As demonstrated by Pitz et al. (2003) and Pitz et al. 2008a the apparent particle density (calculated from PM mass concentration and particle volume concentrations measured in parallel by independent instruments) ranges from 1.0 to $2.5 \mathrm{~g} \mathrm{~cm}^{-3}$ for the 5 th and 95th percentile, respectively depending on the particle composition.

The density of the directly emitted Eyjafjallajökull single ash particles vary between 0.7 and $3.2 \mathrm{~g} \mathrm{~cm}^{-3}$ (Schumann et al., 2011). The calculated densities for single particles sampled directly in the Eyjafjallajökull ash plume over the North Atlantic with the aircraft Falcon vary between 1.7$1.8 \mathrm{~g} \mathrm{~cm}^{-3}$ and $2.0-2.2 \mathrm{~g} \mathrm{~cm}^{-3}$ for particles $<0.5 \mu \mathrm{m}$ and particles $>0.5 \mu \mathrm{m}$ in diameter, respectively (Schumann et al., 2011). This raises the question whether the use of the mean apparent particle density for the whole study period (without specific density assumption for the volcanic dust events) led to additional uncertainties by the calculation of particle mass concentration from particle size distribution.

To answer the question, we calculated the average particle density for $\mathrm{PM}_{2.5}$ and $\mathrm{PM}_{10}$ for the volcanic dust episode in Augsburg. No increase of apparent particle density could be observed, in contrast the apparent particle density for $\mathrm{PM}_{10}$ was $1.28 \mathrm{~g} \mathrm{~cm}^{-3}$ for the time period of the maximal volcanic ash impact on $\mathrm{PM}_{10}$ mass concentrations (19 April 19:00 to 20 April 10:00 UTC+1). It means that the average apparent particle density of $\mathrm{PM}_{10}$ was not changed by volcanic ash particles, probably due to contrary influence of other particulate components in the heterogeneous ambient mixture of different sources. Comparisons of hourly average calculated $\mathrm{PM}_{10}$ mass concentration (using the above-mentioned 
assumptions) from the size distribution of the TDMPS/APS system and independent measurements of $\mathrm{PM}_{10}$ by a Tapered Element Oscillating Microbalance (TEOM) in combination with an Filter Dynamics Measurement System (FDMS) at the same site from 17 to 22 April 2010 (the most important assumable impact of the volcanic ash plume on ground level in Augsburg) resulting in a slope of 0.96 and an intercept of $6 \mu \mathrm{g} \mathrm{m}^{-3}\left(R^{2}=0.84\right)$. Thus, the estimation of particle mass concentration (calculated from particle size distribution) for the volcanic ash event in Augsburg was not biased and it does not require any additional assumption regarding the apparent particle density.

As shown in Fig. 3 the volcanic ash particles contribute to particle mass concentrations mostly in the range between 1 and $10 \mu \mathrm{m}$ in Augsburg. Assuming a mean particle density in this size range of $2.0 \mathrm{~g} \mathrm{~cm}^{-3}$, we estimated the mean difference of $\mathrm{PM}_{10}$ mass concentration for the time period 17 to 22 April 2010 as "worst case" estimation. The calculated average underestimation is $10 \%$ (minimum: $4 \%$, maximum: $15 \%$ ) compared to the $\mathrm{PM}_{10}$ mass concentration calculated by use of a mean apparent particle density of $1.5 \mathrm{~g} \mathrm{~cm}^{-3}$ for the entire size distribution.

Acknowledgements. This work was supported by Helmholtz Zentrum München, German Research Center for Environmental Health (Focus Network Nanoparticles and Health).

Edited by: W. Birmili

\section{References}

Birmili, W., Schepanski, K., Ansmann, A., Spindler, G., Tegen, I., Wehner, B., Nowak, A., Reimer, E., Mattis, I., Müller, K., Brüggemann, E., Gnauk, T., Herrmann, H., Wiedensohler, A., Althausen, D., Schladitz, A., Tuch, T., and Löschau, G.: A case of extreme particulate matter concentrations over Central Europe caused by dust emitted over the southern Ukraine, Atmos. Chem. Phys., 8, 997-1016, doi:10.5194/acp-8-997-2008, 2008.

Birmili, W., Heinke, K., Pitz, M., Matschullat, J., Wiedensohler, A., Cyrys, J., Wichmann, H. E., and Peters, A.: Particle number size distributions in urban air before and after volatilization, Atmos. Chem. Phys., 10, 4643-4660, doi:10.5194/acp-10-46432010, 2010.

Bruckmann, P., Birmili, W., Straub, W., Pitz, M., Pfeffer, U., Hebbinghaus, H., Wurzler, S., and Olschewski, A.: An outbreak of Saharan dust causing high $\mathrm{PM}_{10}$ levels north of the Alps, Gefahrst Reinhalt L, 68, 490-498, 2008.

Colette, A, Favez, O., Meleux, F., Chiappini, L., Haeffelin, M., Morille, Y., Malherbe, L., Papin, A., Bessagnet, B., Menut, L., Leoz, E., and Rouil, L.: Assessing in near real time the impact of the April 2010 Eyjafjallajökull ash plume on air quality, Atmos. Environ., 45, 1217-1221, 2011.

Council Directive 1999/30/EC of 22 April 1999 relating to limit values for sulphur dioxide, nitrogen dioxide and oxides of nitrogen, particulate matter and lead in ambient air. Official Journal of the European Communities, L 163/41, 29th of June 1999, available online at: http://eur-lex.europa.eu/LexUriServ/LexUriServ.
do?uri=OJ:L:1999:163:0041:0060:EN:PDF last access: 2 June 2011, 1999.

Cyrys, J., Pitz, M., Heinrich, J., Wichmann, H. E., and Peters, A.: Spatial and temporal variation of particle number concentration in Augsburg, Germany, Sci. Total Environ., 401, 168-175, 2008.

Directive 2008/50/EC of the European Parliament and of the Council of 21 May 2008 on ambient air quality and cleaner air for Europe. Official Journal of the European Union, L 152/1, 11th of June 2008, available at: http://eur-lex.europa.eu/LexUriServ/ LexUriServ.do?uri=OJ:L:2008:152:0001:0044:EN:PDF, last access: 2 June 2011, 2008.

Emeis, S., Forkel, R., Junkermann, W., Schäfer, K., Flentje, H., Gilge, S., Fricke, W., Wiegner, M., Freudenthaler, V., Gro $\beta$, S., Ries, L., Meinhardt, F., Birmili, W., Münkel, C., Obleitner, F., and Suppan, P.: Measurement and simulation of the 16/17 April 2010 Eyjafjallajökull volcanic ash layer dispersion in the northern Alpine region, Atmos. Chem. Phys., 11, 2689-2701, doi:10.5194/acp-11-2689-2011, 2011.

Flentje, H., Claude, H., Elste, T., Gilge, S., Köhler, U., PlassDülmer, C., Steinbrecht, W., Thomas, W., Werner, A., and Fricke, W.: The Eyjafjallajökull eruption in April 2010-detection of volcanic plume using in-situ measurements, ozone sondes and a new generation ceilometer network, Atmos. Chem. Phys., 10, 10085-10092, doi:10.5194/acp-10-10085-2010, 2010.

Gasteiger, J., Groß, S., Freudenthaler, V., and Wiegner, M.: Volcanic ash from Iceland over Munich: mass concentration retrieved from ground-based remote sensing measurements, Atmos. Chem. Phys., 11, 2209-2223, doi:10.5194/acp-11-22092011, 2011.

Gu, J., Pitz, M., Schnelle-Kreis, J., Diemer, J., Reller, A., Zimmermann, R., Soentgen, J., Stoelzel, M., Wichmann, H. E., Peters, A., and Cyrys, J.: Source apportionment of ambient particles: comparison of Positive Matrix Factorization analysis applied to particle size distribution and chemical composition data, Atmos. Environ., 45, 1849-1857, 2011.

Institute of Earth Sciences (IES), University of Iceland, Eruption in Eyjafjallajökull, http://www.earthice.hi.is/page/ ies_Eyjafjallajokull_eruption, last access: 2 June 2011, 2010.

Ogulei, D., Hopke, P. K., Chalupa, D. C., and Utell, M. J.: Modeling source contributions to submicron particle number concentrations measured in Rochester, New York, Aerosol Sci. Tech., 41, 179-201, 2007.

Paatero, P.: Least squares formulation of robust non-negative factor analysis, Chemometr Intell Lab, 37, 23-35, 1997.

Paatero, P.: The multilinear engine-a table-driven, least squares program for solving multilinear problems, including the $\eta$-way parallel factor analysis model, J. Comput. Graph. Stat., 8, 854-888, 1999.

Paatero, P. and Tapper, U.: Positive matrix factorization: a nonnegative factor model with optimal utilization of error estimates of data values, Environmetrics, 5, 111-126, 1994.

Pitz, M., Cyrys, J., Karg, E., Wiedensohler, A., Wichmann, H. E., and Heinrich, J.: Variability of apparent particle density of an urban aerosol, Environ. Sci. Technol., 37, 4336-4342, 2003.

Pitz, M., Schmid, O., Heinrich, J., Birmili, W., Maguhn, J., Zimmermann, R., Wichmann, H. E., Peters, A., and Cyrys, J.: Seasonal and diurnal variation of $\mathrm{PM}_{2.5}$ apparent particle density in urban air in Augsburg, Germany, Environ. Sci. Technol., 42, 5087-5093, 2008a. 
Pitz, M., Birmili, W., Schmid, O., Peters, A., Wichmann, H. E., and Cyrys, J.: Quality assurance of aerosol particle size distribution measurements at an urban air pollution monitoring station in Augsburg, Germany, J. Environ. Monitor., 10, 1017-1024, 2008b.

Schäfer, K., Thomas, W., Peters, A., Ries, L., Obleitner, F., Schnelle-Kreis, J., Birmili, W., Diemer, J. Fricke, W., Junkermann, W., Pitz, M., Emeis, S., Forkel, R., Suppan, P., Flentje, H., Wichmann, H. E., Gilge, S., Meinhardt, F., Zimmermann, R., Weinhold, K., Soentgen, J., Münkel, C., Freuer, C., and Cyrys, J.: Influences of the 2010 Eyjafjallajökull volcanic plume on air quality in the northern Alpine region, Atmos. Chem. Phys., 11, 8555-8575, doi:10.5194/acp-11-8555-2011, 2011.

Schumann, U., Weinzierl, B., Reitebuch, O., Schlager, H., Minikin, A., Forster, C., Baumann, R., Sailer, T., Graf, K., Mannstein, H., Voigt, C., Rahm, S., Simmet, R., Scheibe, M., Lichtenstern, M., Stock, P., Rüba, H., Schäuble, D., Tafferner, A., Rautenhaus, M., Gerz, T., Ziereis, H., Krautstrunk, M., Mallaun, C., Gayet, J. F., Lieke, K., Kandler, K., Ebert, M., Weinbruch, S., Stohl, A., Gasteiger, J., Groß, S., Freudenthaler, V., Wiegner, M., Ansmann, A., Tesche, M., Olafsson, H., and Sturm, K.: Airborne observations of the Eyjafjalla volcano ash cloud over Europe during air space closure in April and May 2010, Atmos. Chem. Phys., 11, 2245-2279, doi:10.5194/acp-11-2245-2011, 2011.
Thomas, H. E. and Prata, A. J.: Sulphur dioxide as a volcanic ash proxy during the April-May 2010 eruption of Eyjafjallajökull Volcano, Iceland, Atmos. Chem. Phys., 11, 6871-6880, 2011, http://www.atmos-chem-phys.net/11/6871/2011/.

Volcanic Ash Advisory Centres (VAAC). United Kingdom National Weather Service Met Office, http://www.metoffice.gov.uk/ aviation/vaac/, 2010.

Yue, W., Stölzel, M., Cyrys, J., Pitz, M., Heinrich, J., Kreyling, W. G., Wichmann, H. E., Peters, A., Wang, S., and Hopke, P. K.: Source apportionment of ambient fine particle size distribution using positive matrix factorization in Erfurt, Germany, Sci. Total Environ., 398, 133-144, 2008.

Zhou, L. M., Kim, E., Hopke, P. K., Stanier, C. O., and Pandis, S.: Advanced factor analysis on Pittsburgh particle size-distribution data, Aerosol Sci. Technol., 38, 118-132, 2004. 